\title{
カード検索機を使用しての 雑誌記事の検索
}

\section{は じめに}

医学の進歩に伴い，医学で扱う情報は，量の增大の及 ならず，内容もますます複雑化し高度化している。それ ゆ光に，情報を迅速かつ的確に収集，管理，分析し，利 用者からの要求に応じた適切なサービスが要望されてい る。しかし, 当館のような小規模な図書館 (職員の定員 6 名, 現在 5 名) に执いては, 専従のレファレンサーを おくことは困難である。

このような現状を打破するための一手段として，文献 の項目等をカード化し，そして利用者自らが検索機を操 作することにより，文献を迅速化しょうとするものであ る。洋雑誌に揭載されている論文の検索については, In-
木 下 順一*

dex Medicusや, MEDLARSにより，大変便利になっ ているが，和雑誌のそれらについては，不備な点があ り，利用者から不満な声を聞くことがたびたびある。そ こで，当館もおくればせながら，1971年より始めた『和 雑誌の特集記事索引』にかなりの利用率があることに注 目し，今回の作業計画をたてることにした。

作業は開始したばかりなので，内容，プログラムの方 法などで今後まだまだ改良しなければならない点がある と思われるが，以下に作業方法の詳細を述べ，皆様のご 指摘及びご批判を期待したい。

\section{§1. 使用機種と目的}

タナックカード検索機 $530 \mathrm{MP}$ 型を使用する。当館で

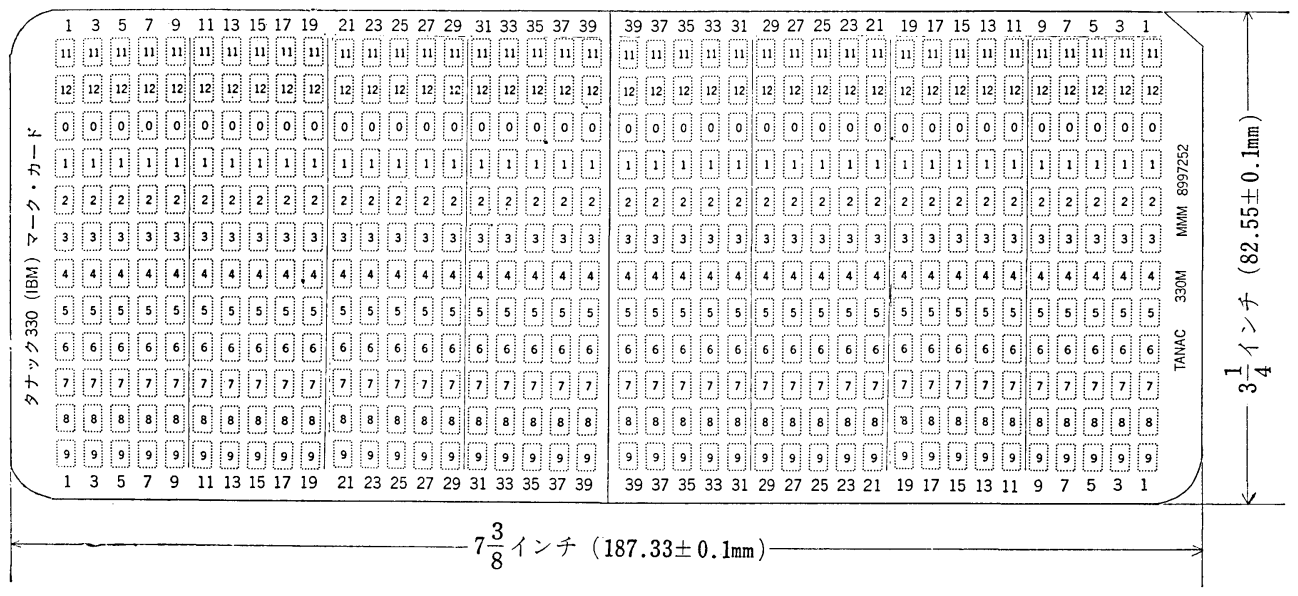

第 1 図

* Jun’ichi KINOSHITA, 大阪市立大学附属図茟館医学部分館 


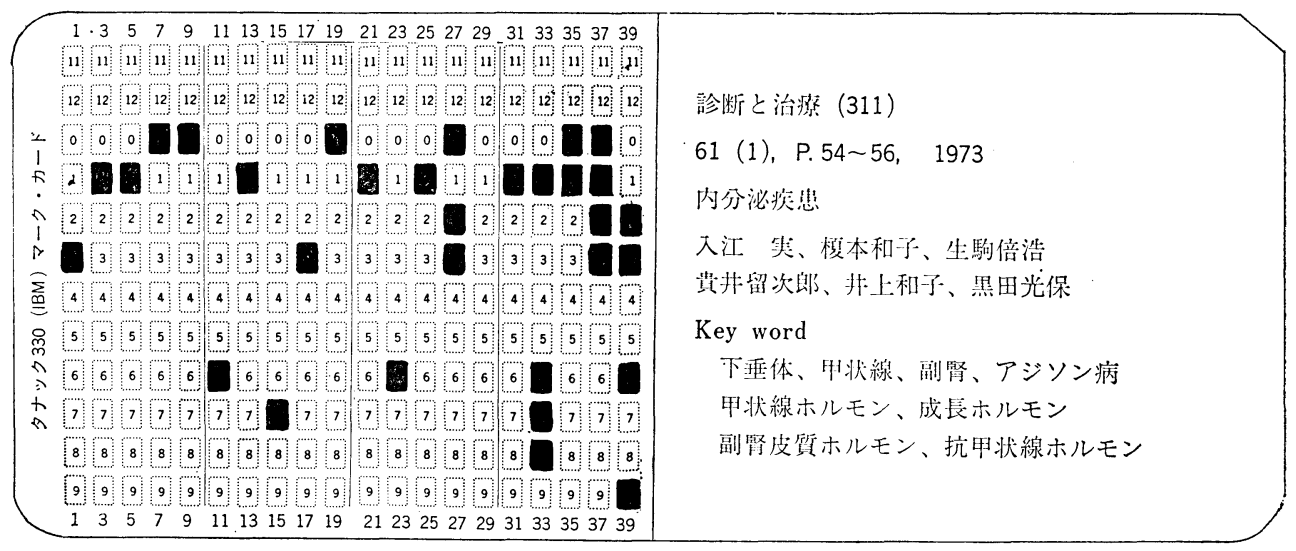

第 2 図カードの一例

所蔵する和雑誌で特集記事として揭載されている文献を すべて検索できるように作業を進める。当面, 特集記事 に限るのは, 現状から作業量と時間に問題があるためで ある。

\section{§. カ - ド}

現段階では，試作検討中なので，当面はタナック 330 (IBM) マークカードを使用するが，いずれは，別製力 一ドを印刷する予定である。（現段階におけるマークカ ードの一例を［図2］に示す。）

[図 1] は, マークカードの実物大を示す。大きさは, 崼 $3^{1} / 4$ インチ $(82.55 \pm 0.1 \mathrm{~mm})$ 横 $73 / 8$ インチ $(187.33$ $\pm 0.1 \mathrm{~mm})$, 厚さ $0.00625 \sim 0.00725$ インチ $(0.159 \sim$ $0.184 \mathrm{~mm}$ ) で, 表面に 480 個の長方形を黑くぬりつぶ し（以下マークと呼ぶ）この印のあるかないかにより， 選別する。( 1 枚のカードを 1 回で選別できるのは, 左半分の 240 個にマークされた部分である。）カードを まげたり折ったり，よごしたりすると，検索機でつまる などの故障をおこすので，特に注意しなければならな W。

\section{$\S 3$. 検索機の機能}

検索機には，第 1 回路と第 2 回路の 2 回路があり，第 1 回路は, カードのマークの位置が指示の位置とすべて 一致するとき，そのカードが選別される回路で，いわば

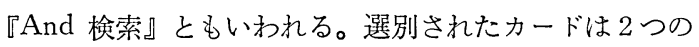

ストッカーに入るようになっている。

第 2 回路は, カードのマークの位置が指示した位置の

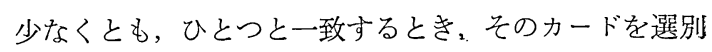
する回路である。いわば『Or 検索』ともいわれる。上 の 2 つ And と Or の検索を肯定といら考えかたをす れば，それらの否定は（残りのカードのこと）Not 検索 ともいえる。

例えば，件名 (Key Word) を高血圧症 (C08068) と 降圧剂 (D05010) とし, 検索機に指示を与えるとす ると, And 回路の場合は, 高血圧症 (C08068) と降圧剤 (D05010) の両方にマークされたカードのみを選別する ので, [図 3] のカードは検索されるが, どちらか一方 しかマークされてないカードは検索されない。

Or 回路を使うと, 高血圧症 (C08068) か, 降圧剤 (D05010) の一方がマークされてあれば検索可能な機種 もある。今回のコード方法で当館の使用機種の場合は, Or 回路を使って検索することはできない。

検索機で一回に検索される最高カード枚数は, 約 500 枚で, 所要時間 1 分程度である。

\section{§4. コードのしかた}

カードのコードのしかたは，直接コード，単純組合せ （不完全選択性）コード, 限定組合せ（完全選択性）コ ードなどと複合したものとがある。

ここでは, 単純組合せと限定組合せコードの両方を用 いることにした。

先ず, このカードにより何が検索されるのかといえ 


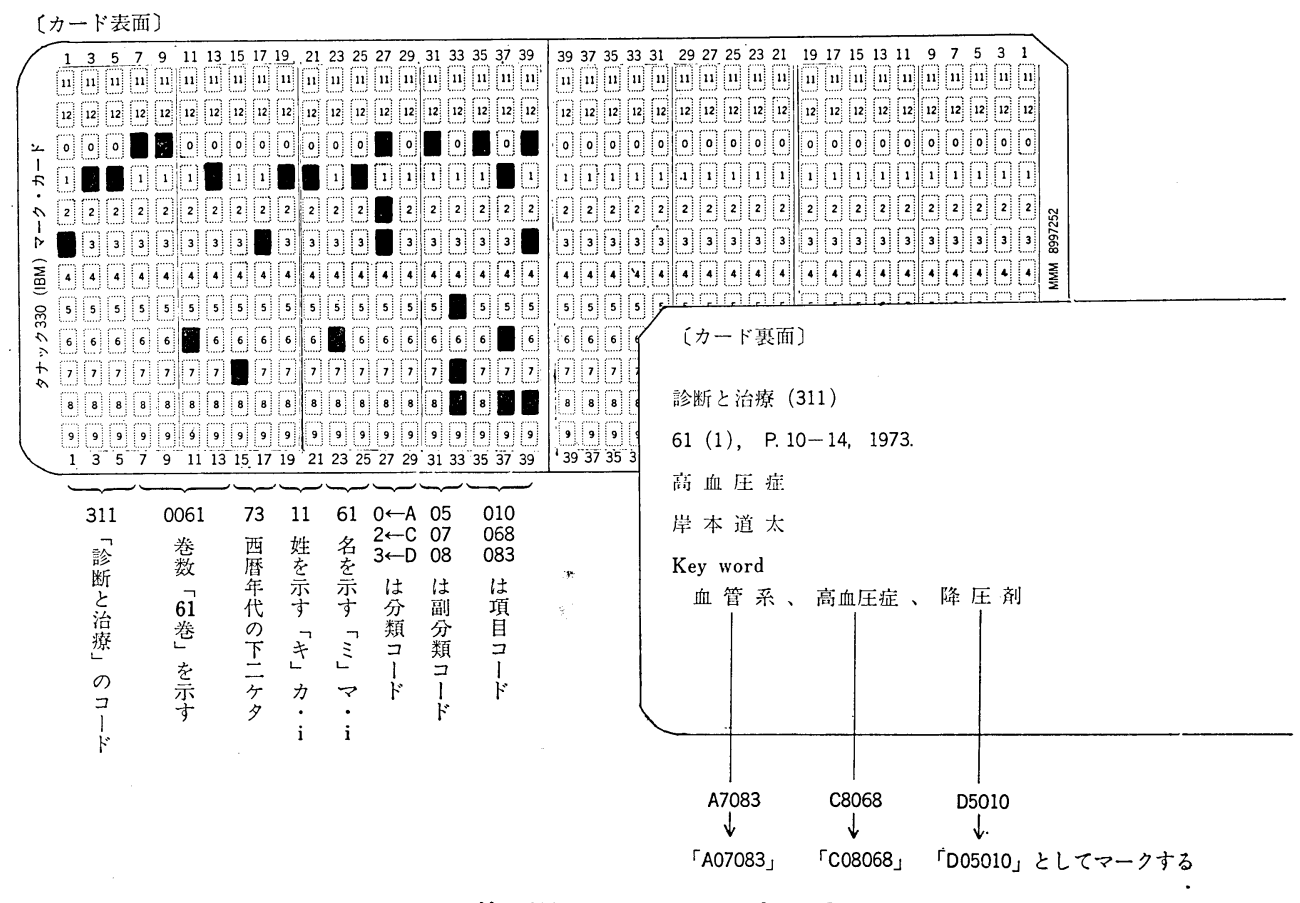

第 3 図カ $ー ト ゙$ 表 面

ば, 雑誌名, 巻 (Vol. or No (日本医事新報のみ)), 年 代，著者名，(共著の場合，第一著者），件名（論文のキ ーワード)の 5 項目についてである。図 $3 ， 4$ を見てい ただきながら説明を進めることにする。

カードの左から 3 列（上に記した番号 $1 \sim 5$ (以下数 字のみ記す)）には，雑誌名のコード番号を記入する。 このコード番号は, 当館で発行している 1972 年度版の 『学術雑誌受入目録』の番号を用いることにした。左 4 列目から 7列目（7１3）には，巻を記入することにし た。

左から，8，9列目 $(15 ， 17)$ には, 年代（西暦年代 1900 年をとった，下 2 ケタ）を記入することにした。左 10 列目から 14 列目（19２5）には，著者名を記入する ことにした。(19，21には，著者の姓の最初の1文字を， 23，25には，名の最初の 1 文字を，子音と母音，その 他，半濁音，濁音を組合すことにより表す。）最後に左 15 列目から 20 列目（27 39）には，件名（論文の Key Word）を記入することにした。このカードで一番問題 にされるのは，この件名，(Key Word)の項である。少 しでも多くの件名について探索できるょうにと，種々検 討した結果, Index Medicus (Vol. 13，1972)の Medi- cal subject headings を用いることにした。これらは， 件名を $\mathrm{A} \sim \mathrm{N}$ の 14 に分類（図 5 を参照）し，1分類 は，1〜17 (多いもので) に副分類されている。

副分類はさらにA B C 順の項目別化されている。図 6 参照)。

Medical subject headings をコード化するために, 次 のようにした。

即ち, 分類, 副分類, 項目 3 のつを組合せ, コード化 したが，その一例を図 6 に示した。

\section{$\S 5$ おおりに}

現在, 情報の収集と整理のために、コンピューターを 用い，大がかりに進められているところがあるが，それ はすべて企業によるもので，企業秘密のため，方法につ いては，一切発表されていない。また，MEDLARS (Medical Literature Analysis and Retrieval System.) は, コンピューターを利用して開発された医学生物学の 分野の情報システムで，世界各地にセンターをおいて， ネットワークを形成している大がかりなものであるが， わが国でのネットワークはまだ確立していない。しか 
も有料である。今回の作業は，当館独自で機械力を導入 し，論文の検索を容易にしょうとするものである。

将来は, 当大学計算センター等の大型コンピューター から端末器をひくことにより,ささら論文の収集範囲を
広げていくこと等も考えられる。

（図 7）に，作業手順について図式化したので，つけ 加えていただきたい。

（昭和 48 年 5 月 30 日 受付）

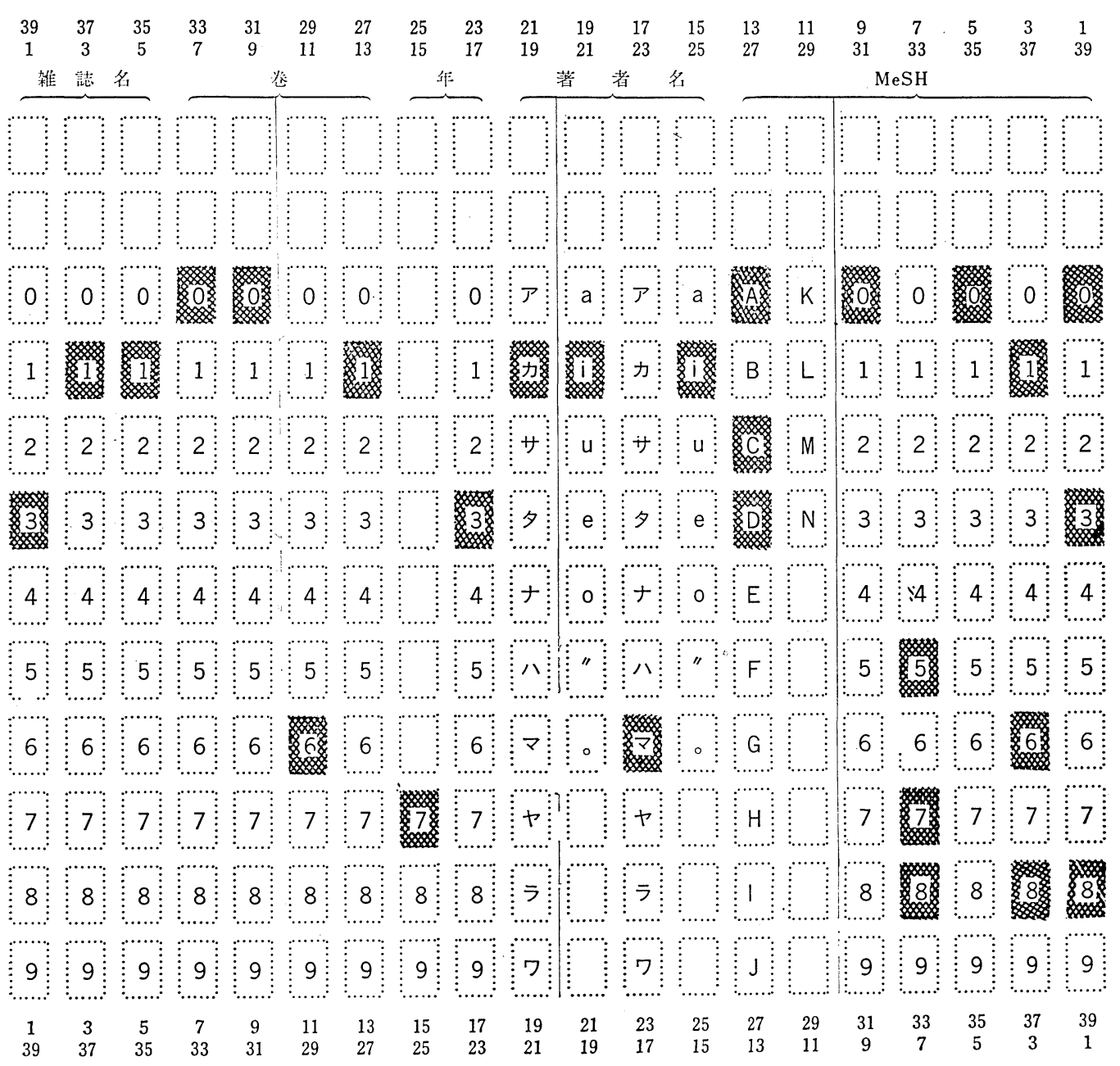

図4 カ 
〔図 5〕分類と副分類

MEDICAL S
Categories
sj

D Chemicals and Drugs ............ 320

D1 Inorganic Chemicals - Elements, Simple Compounds, and Related Terms..... 320

D2 Organic Chemicals and Structural Groups $\ldots \ldots \ldots \ldots \ldots \ldots \ldots .6324$

D3 Anti-Infective Agents and Pesticides.... 334

D4 Antineoplastic Agents and Immunosuppressive Agents $\ldots \ldots \ldots \ldots \ldots \ldots, 338$

D5 Autonomic Drugs, Cardiovascular Agents, Muscle Relaxants ............. 340

D6 CNS Drugs, Antiemetics, Antihistaminics, Antitussive Agents ............. 344
D7 Hematologic Agents, Gastrointestinal Agents, Agents for Fluid Therapy $\quad \ldots \quad 348$

D8 Hormones, Precursors, Metabolites, Substitites and Antagonists ....... 350

D9 Enzymes, Coenzymes, Enzyme Inhibitors and Precursors ............... 354

D10 Amino Acids, Peptides, Proteins and Nucleic Acids $\ldots \ldots \ldots \ldots \ldots \ldots \ldots, 358$

D11 Carbohydrates, Lipids, Vitamins and Related Compounds .......... 362

D12 Immunologic Factors, Biological Factors and Substances ............. 366

D13 Miscellaneous Chemicals and Drugs .... 368

E Analytical, Diagnostic and Therapeutic Technics and Equipment . ......... 372

E1 Diagnostic Techrics and Equipment .... 372

E2 Preventive and Therapeutic Technics and Equipment .............. 376

E3 Anesthetic Technics and Equipment.... 378

E4 Surgical Technics and Equipment ..... 380

E5 Miscellaneous Technics, Methods and Equipment................ 384

E6 Dentistry $\ldots \ldots \ldots \ldots \ldots \ldots \ldots \ldots \ldots \ldots \ldots \ldots, 386$

F Psychiatry and Psychology .......... 388 iF 1 Psychologic Mechanisms and Processes.. 388 F2 Behavioral Symptoms and Mental Disorders ................. 394

F3 Behavioral Sciences, Psychological Tests, Psychotherapy, Services ......... 398

G Biological Sciences ............. 400 G1 Biological Sciences and Biological Phenomena ............... 400

G2 Health Occupations and Disciplines .... 408

G3 Environmental Health, Hygiene and Preventive Medicine ........... 410

H Physical Sciences ................. 412

I Anthropology, Education, Sociology and Social Phenomena ................ 416

J Technology, Commerce and Industry ..... 420

K Humanities .................. 422

L Communication, Library Science and Documentation ................. 424

M Named Groups of Persons .......... 426

N Health Care $\ldots \ldots \ldots \ldots \ldots \ldots \ldots \ldots, 428$

N1 Population Characteristics .......... 428

N2 Health Faciiities, Manpower and Services 430

N3 Economics, Organizations, Social Control .................. 434

N4 Health Services Administration......... 436 
A-ANATOMICAL TERMS

Al-Parts of the Body

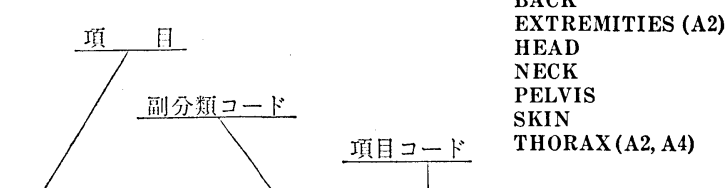

\section{ABDOMEN}

BACK

EXTREMITIES (A2)

項目コード THORAX (A2, A4)

項目コード

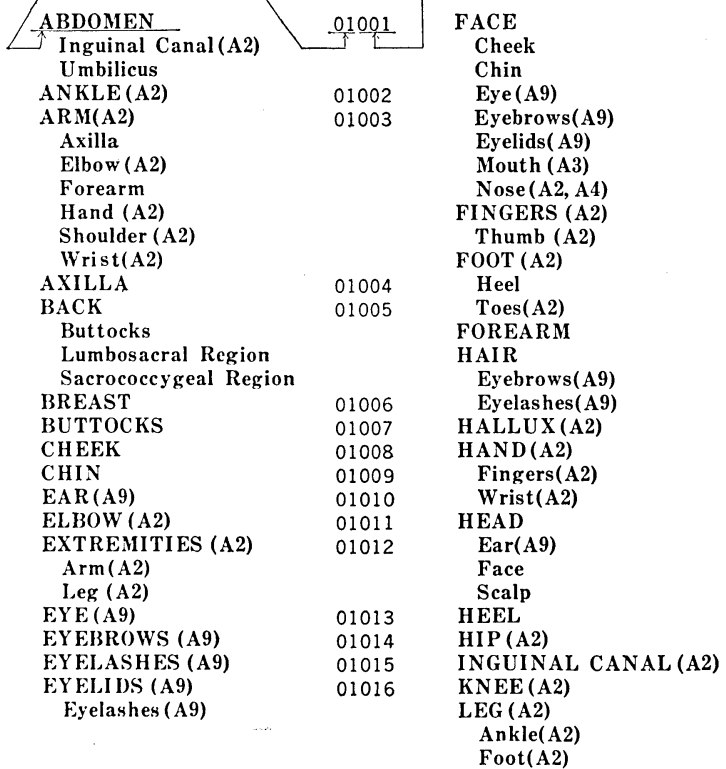

\begin{tabular}{|c|c|c|}
\hline \multirow[t]{5}{*}{01017} & $\begin{array}{l}\text { LEG (A2)(Continued) } \\
\text { Hip (A2) } \\
\text { Knee(A2) } \\
\text { Thigh }\end{array}$ & 01030 \\
\hline & $\operatorname{LIP}(\mathbf{A} 3)$ & 01031 \\
\hline & LU MBOSACRAL REGION & 01032 \\
\hline & MEDIASTINUM & 01033 \\
\hline & MOUTH (A3) & 01034 \\
\hline \multirow[t]{2}{*}{01018} & Lip (A3) & \\
\hline & NAILS & 01035 \\
\hline \multirow[t]{3}{*}{01019} & NECK & 01036 \\
\hline & $\operatorname{NOSE}(A 2, A 4)$ & 01037 \\
\hline & PELVIS & 01038 \\
\hline 01020 & PERINEUM & 01039 \\
\hline \multirow[t]{3}{*}{01021} & SACROCOCCYGEAL REGION & 01040 \\
\hline & SCALP & 01041 \\
\hline & SEBACEOUS GLANDS & 01042 \\
\hline 01022 & SHOULDER (A2) & 01043 \\
\hline \multirow[t]{3}{*}{01023} & SKIN & 01044 \\
\hline & Hair & \\
\hline & Nails & \\
\hline \multirow[t]{3}{*}{01024} & Scalp & \\
\hline & $\begin{array}{l}\text { Sebaceous Glands } \\
\text { Sweat Glands }\end{array}$ & \\
\hline & SWEAT GLANDS & 01045 \\
\hline & THIGH & 01046 \\
\hline 01026 & THORAX (A2, A4) & 01047 \\
\hline 01027 & $\begin{array}{l}\text { Mediastinum } \\
\text { THUMB (A2) }\end{array}$ & 01048 \\
\hline 01028 & TOES (A2) & 01049 \\
\hline \multirow[t]{3}{*}{01029} & Hallux (A2) & \\
\hline & UMBILICUS & 1050 \\
\hline & WRIST (A2) & 01051 \\
\hline
\end{tabular}

図 6 副分類と項目の一例

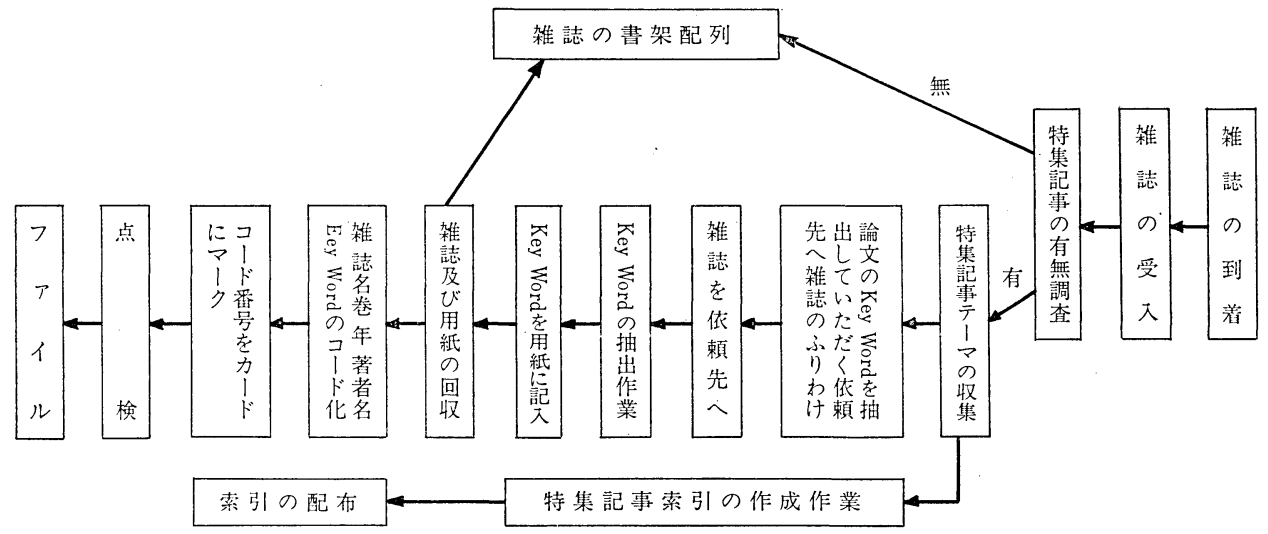

この項は当館で現在実施中

図 7 雑誌の到着カードにマークされるまで（案） 